\title{
Geometrische Transformationen als Entwurfsmethodik
}

\author{
Cornelie Leopold
}

Abstract

Transformation, lateinisch transformare bedeutet umformen, ist ein zentraler Begriff in der architektonischen Gestaltung. In der Geometrie bzw. Mathematik wurde der Begriff derTransformation grundlegend. Transformation ist mit der Idee der Morphologie und Metamorphose verbunden, die für die Beschreibung von Wachstumsprozessen eine Rolle spielen. Der architektonische und der geometrische Transformationsbegriff sollen genauer untersucht und dessen Rolle für eine Methodik des architektonischen Entwerfens analysiert werden. Exemplarisch soll ein Blick auf Entwurfsmethodiken von Jean-Nicolas-Louis Durand, Oswald Mathias Ungers und Roland Knauer geworfen werden, bei denen Transformationen zur Anwendung kommen.

Der mathematisch-geometrische Transformationsbegriff hat eine neue Denkweise begründet, durch den Abbildungen bzw. Transformationen unter dem Aspekt ihrer Invarianten gegliedert werden. Die Invarianten der betreffenden Transformationen sind diejenigen Eigenschaften geometrischer Objekte, die bei Anwendung der betreffenden Transformationen unverändert bleiben. Felix Klein hat 1872 in seinem Erlanger Programm mit dieser Sichtweise die Geometrie neu strukturiert.

Wie dieser Ansatz auch in der Architekturentwurfsmethodik Anwendung finden kann, soll im weiteren Verlauf anhand einiger Beispiele von Architekturstudierenden erläutert werden. Dabei werden die Transformationen geometrisch gliedert und für architektonische Gestaltungsprozesse nutzbar gemacht.

Keywords

Transformation, Entwurfsmethodik, Geometrie, Morphologie.

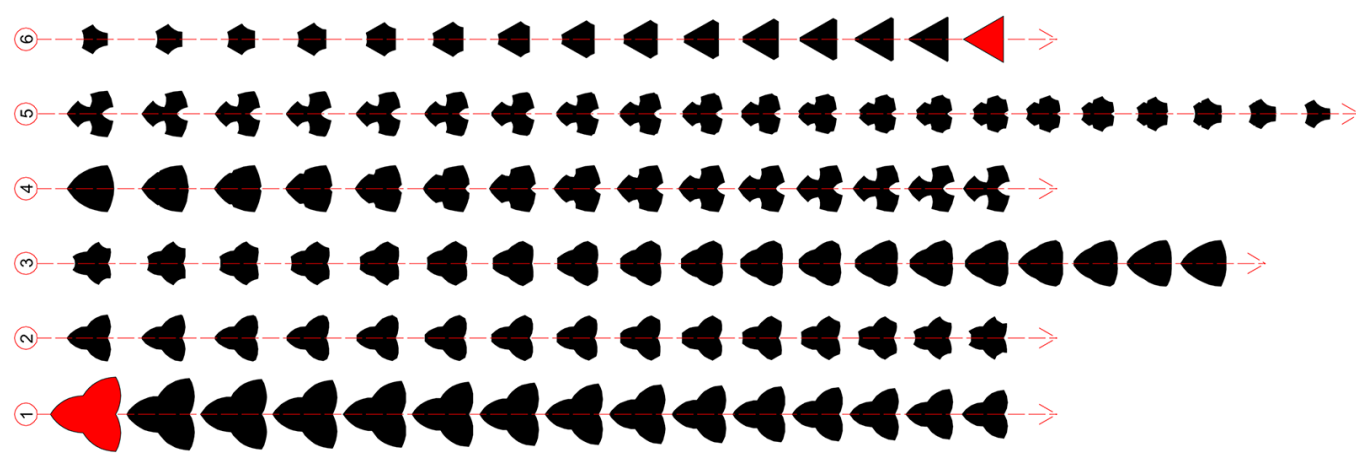




\section{Begriff der Transformation}

Transformation bedeutet Umformung, Umgestaltung, Umwandlung und damit übergehen von einem Zustand in einen anderen. In der Natur ist die Transformation ein ständiger Prozess, zum Beispiel vom Samenkorn zur Pflanze, aber auch bei der Verwandlung der Natur im Laufe der Jahreszeiten. Die Transformation ist damit auch verbunden mit der Morphologie, der Formen und Gestaltlehre. Der Begriff wurde von Goethe in die Wissenschaft eingeführt [Goethe |8|7, p. 6]. Er erklärt die Komplexität organischer Körper als je spezifische "Metamorphose", also Umwandlung bzw. Transformation einer einfachen Grundform. Diese Gedanken können wir auf die architektonische Gestaltung übertragen und damit für Entwurfsprozesse wirksam werden lassen. D'Arcy Wentworth Thompson untersucht in seinem Buch Über Wachstum und Form von 1917 den Zusammenhang von Wachstumsprozessen und Form, stellt insbesondere in seinerTheorie der Transformationen einen Zusammenhang zwischen physikalischen Kräften und mathematischer Form bzw. Formveränderung her. Transformation sieht er verbunden mit dem Entstehen und Werden von Form bzw. der Wandlung einer Form in eine andere Form [Thompson, 1917, pp. 379f.]. Damit ist eine Anwendung als Entwurfsmethodik in dem Begriff der Transformation bereits angelegt.

\section{Transformation in der architektonischen und gestalterischen Entwurfsmethodik}

Oswald Mathias Ungers spricht in Die Thematisierung der Architektur von dem „Thema der Transformation oder die Morphologie der Gestalt": „Alle Geschehnisse, sowohl die natürlichen als auch die durch den Menschen bedingten, folgen mehr oder weniger den Gesetzen der Formation und Transformation. Die beiden Prozesse bedingen sich gegenseitig [...] In diesem Zusammenhang gesehen kann das Phänomen der Transformation entscheidende Impulse auf das kreative Denken ausüben, denn es lehrt nicht nur das Denken in Gegensätzen und Alternativen, sondern vor allem in komplexen Zusammenhängen" [Noebel 20I I, p. 19].

Er schreibt der Transformation ein gestalterisches Prinzip zu. Die morphologische Transformation sieht er als Gestaltungsmittel. Ausgehend von drei geometrischen Grundformen, Quadrat, Dreieck und Kreis, entwirft Ungers ein unvollendetes morphologischen Formlexikon. Er baut dabei auf der Theorie Jean-Nicolas-Louis Durands auf, der in seinem Werk Précis des Leçons d'Architecture, I802, ebenfalls von Grundformen, Quadrat und Kreis (fig. I), ausgeht und mit Hilfe von Teilungen sowie Kombinationen eine Entwurfslehre entwickelt.

Fig. I. Gebäudeensembles als Ergebnisse aus des Quadrats, des Parallelogramms Parallelogramms und ihrer Kombination mit dem Kreis von Durand 20, pp. 253, 254].

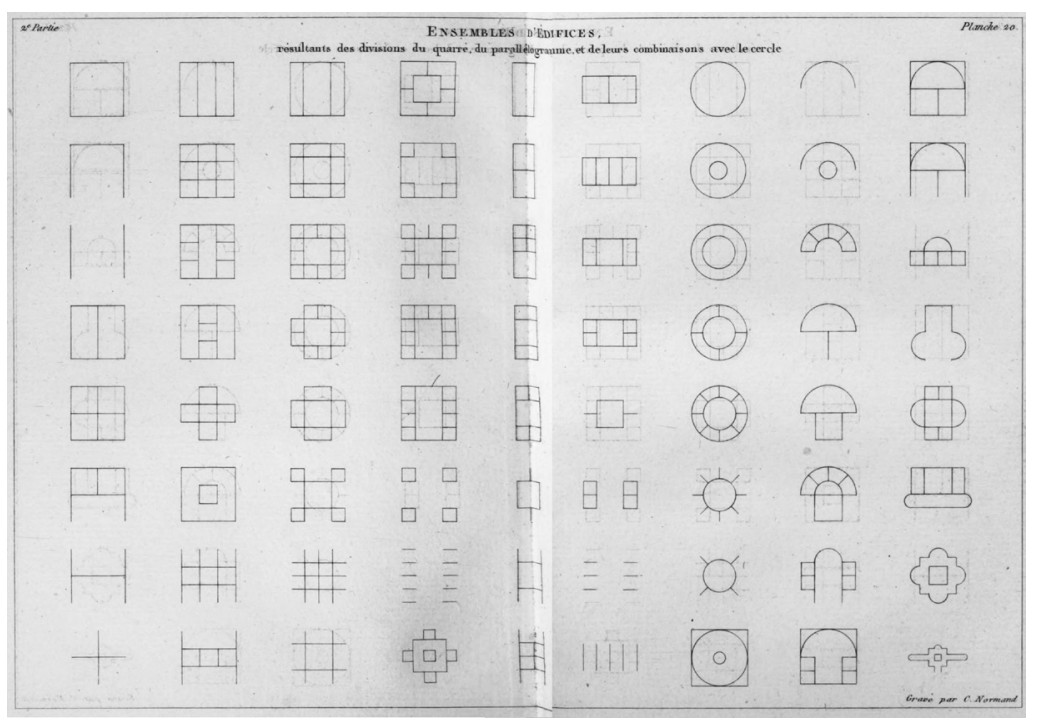


Fig. 2. Morphologie der drei Grundformen Quadrat, Kreis und Dreieck von O.M. Ungers, 1964 [Noebel 201],
Er fügt hinzu, dass auf der Tafel 20 der Blick auf das Prinzip der Unterteilungen gerichtet werden sollte. Die verschiedenen horizontalen Anordnungen sollte man sich jeweils auch im Raum vertikal vorstellen, denn es sei nicht möglich, die große Zahl an möglichen Kombinationen vollständig darzustellen.

Ungers hatte seinen Ansatz von Durand aufgegriffen und weitergeführt. Ungers spielt seinen Ansatz des morphologischen Formlexikons am Entwurf für das Studentenwohnheim Enschede in Holland von 1963 durch. Er beschreibt die verwendeten Transformationen auf die drei Grundformen als Brechung, Beugung, Teilung, Umkehrung, Verdopplung, Spiegelung, Reihung, Wiederholung, Überlagerung, etc. Diese Transformationen möchte er nicht nur auf die Grundformen selbst, sondern auch auf deren raumbildende Fähigkeit anwenden. Aufgrund der möglichen Vielfalt gab Ungers jedoch diesen theoretischen Ansatz einer Enzyklopädie der Raum und Körperformen auf. In der konkreten Entwurfssituation betrachtete er diese Vorgehensweise mittels Transformationen jedoch als erfolgreich.

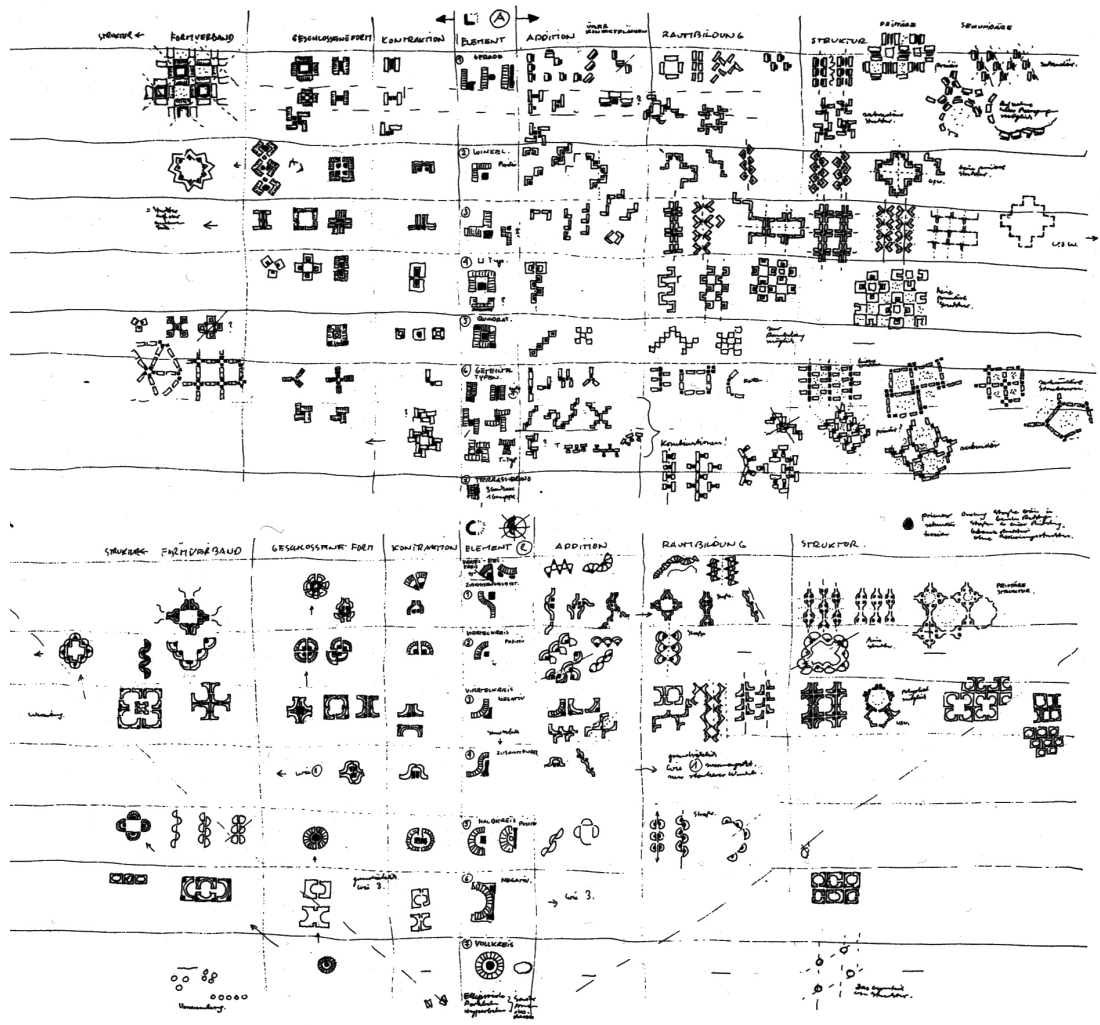

Sein morphologisches Formlexikon (fig. 2) gliedert Ungers in die Spalten: Struktur, Formverband, geschlossene Form, Konstruktion, Element, Addition, Raumbildung, Struktur. Er entwickelt damit aus der Grundform bzw. Grundstruktur über die angegebenen Prozesse bzw. Kriterien komplexe Strukturen.

Roland Knauer, Professor an der Hochschule für Gestaltung in Schwäbisch Gmünd, schuf aufbauend auf den Transformationsbegriff eine Methodik des Gestaltens. Dabei geht er von Formen und Strukturen eines basishaften Repertoires aus, Punkt, Linie, Stab, Fläche und Körper die über eine Transformationsgrammatik im ästhetischen Prozess zum Entwurf werden. Jede komplexe Gestalt versteht er als Variation aus diesen Basiselementen. Er denkt sich diese Basiselemente also direkt räumlich und nicht als ebene geometrische Figuren wie Durand und Ungers, wobei auch diese auf die räumliche Interpretation hinweisen. Knauer beginnt mit dem Element Stab, das sich durch Veränderungen von Querschnitten, Achsenlagen, Krümmungen, Verdrehungen, Volumenveränderungen verwandelt. Aus Anordnungen 
und Lagerelationen entstehen unterschiedliche Verbindungsmöglichkeiten. Der Weg der Gestaltung geht bei Knauer dann über mögliche Gitter hin zur Körperbildung (fig. 3). Körperpackungen sind Vorbild für das Zusammenfügen von Körpern zu einem komplexeren Ganzen. Körpergliederungen verbunden mit den Operationen wie Subtraktion und Addition sowie Transformationen derTeilkörper lassen eine Vielfalt an neuen Kompositionen entstehen.

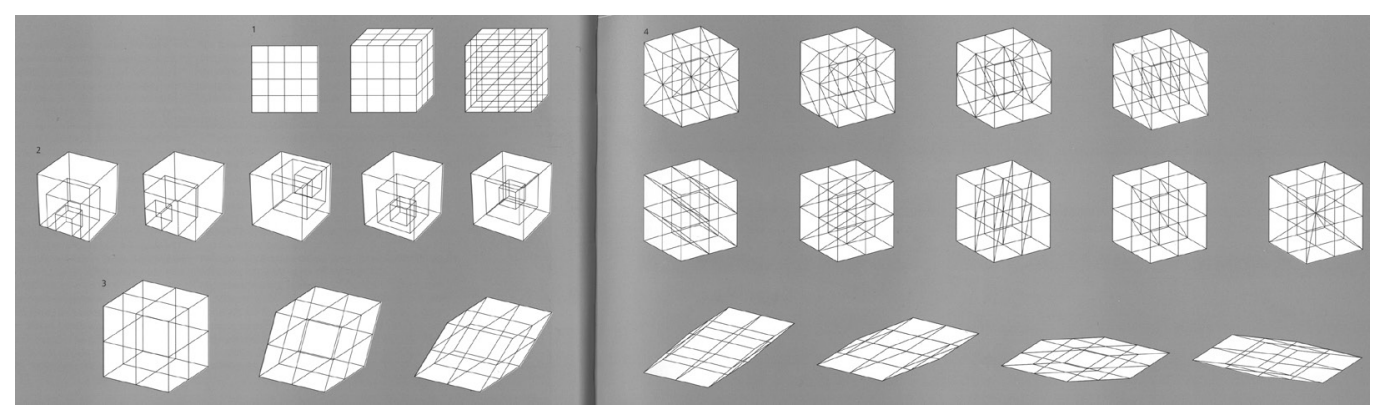

\section{Geometrischer Transformationsbegriff}

Der mathematische Transformationsbegriff ist eng mit dem Begriff der Abbildung, gleichbedeutend mit Funktion, verbunden, der in vielfältigen Zusammenhängen verwendet wird. Im Zusammenhang der Mengentheorie wurde er zur essentiellen Grundlage mit universeller Anwendung: jedem Element $x$ einer Menge $X$ wird ein eindeutiges Element $y$ einer Menge $Y$ zugeordnet. Das Element $y$ wird dann auch als das Bild von x auf der Grundlage der verwendeten Abbildung bezeichnet. Die zugrundeliegende Vorstellung bezieht sich also klar auf das geometrische Verständnis des Erzeugens eines Bildes eines räumlichen Objektes und damit auf die Projektion als Grundbegriff der Darstellenden Geometrie. Emil Müller beschrieb in seiner Antrittsrede als Rektor der Technischen Hochschule Wien 1912 das Abbildungsprinzip als ein Forschungsprinzip, das in der Mathematik und ihren Anwendungsgebieten, aber auch weit über die Mathematik hinaus ,,ja eigentlich all unser Denken und Forschen beherrscht" [Müller 1913, p. 45].

Wenn zwei geometrische Figuren aufeinander abgebildet werden, so sagt man, sie sind geometrisch verwandt. Solche Verwandtschaften sind Kongruenz, Ähnlichkeit, Affinität und Kollineation. Diese geometrischen Verwandtschaften können sowohl in der Ebene als auch im Raum bzw. allgemeiner in mathematischen Räumen beschrieben werden. Betrachtet werden dann die Eigenschaften der Figuren, die bei der Abbildung unverändert, d.h. invariant, bleiben. Es war die Errungenschaft Felix Kleins [Klein 1872], die verschiedenen Geometrien über die Invarianten der jeweiligen Abbildung bzw. Transformation zu ordnen. Klein verwendet den Begriff der Transformation. Zuvor hatte schon August Ferdinand Möbius 1827 in seinem Werk Der barycentrische Calcul die Verwandtschaft geometrischer Figuren behandelt. Diese Verwandtschaften gliederte er bereits in Gleichheit (Kongruenz), Ähnlichkeit und Kollineation. Felix Klein hat schließlich in seinem „Erlanger Programm" die Geometrie bzw. Geometrien mit dem Transformationsbegriff verknüpft und mit dem ursprünglich in der Algebra entwickelten Begriff der Gruppe auf eine neue Grundlage gestellt. Geometrie wird verstanden als die Disziplin, die die Eigenschaften von Figuren untersucht, die bei Lageänderungen erhalten bleiben, die Invarianten der Transformation. Er nimmt daher eine Klassifizierung mittels der jeweils zugelassenen geometrischen Transformationen vor. Die einer Geometrie zugehörigen Transformationen bilden bezüglich ihrer Hintereinander-Ausführung eine Gruppe, die sogenannte Transformationsgruppe der Geometrie. Die in der betreffenden Geometrie untersuchten Eigenschaften bleiben bezüglich aller Transformationen der Transformationsgruppe invariant. Damit werden die Transformationen selbst zum grundlegenden Element der Geometrie und nicht mehr die 
geometrischen Figuren. Ergänzend kann die Topologie als Geometrie hinzugefügt werden, bei der als Invariante nur die Nachbarschaft, also Zusammenhangsverhältnisse vorkommen. In der Tabelle in fig. 4 haben March und Steadman die jeweilige Transformation durch die entsprechende Invariante gekennzeichnet.

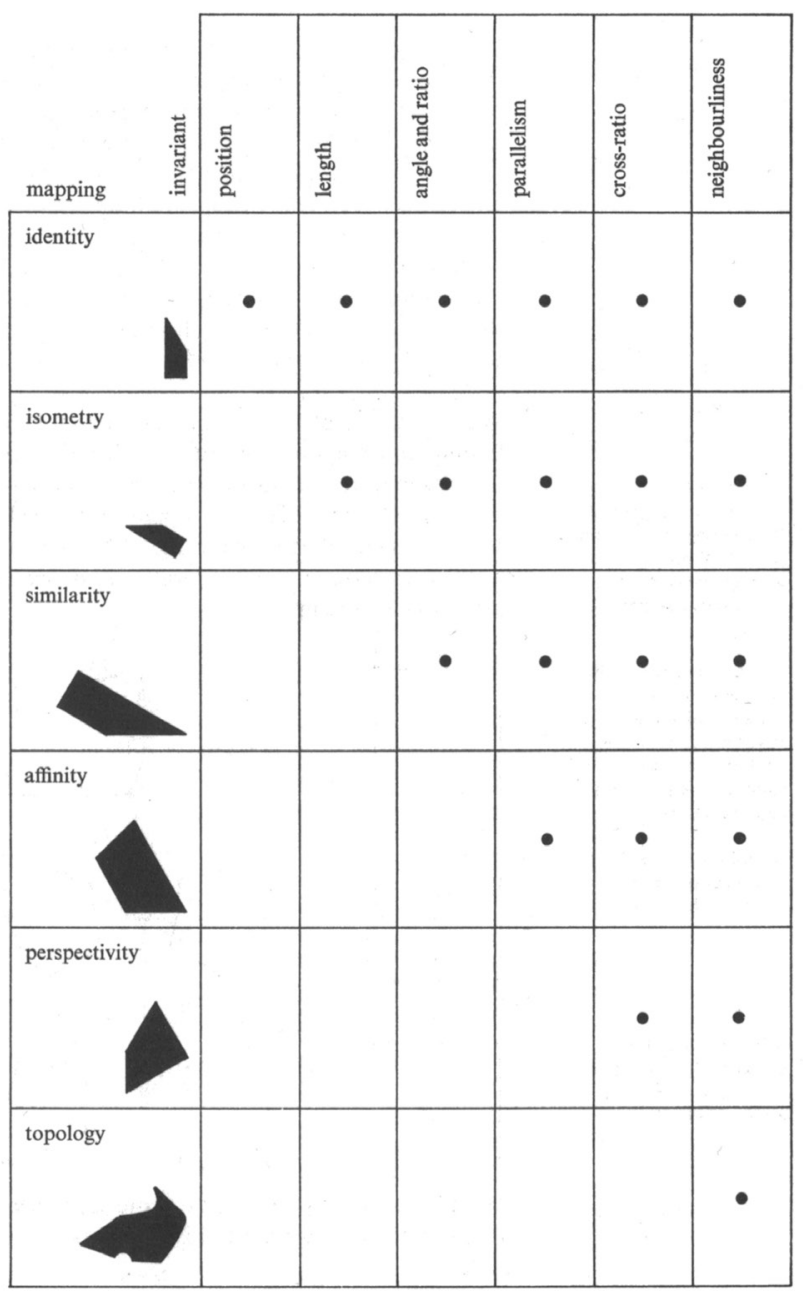

Die elementare euklidische ebene oder räumliche Geometrie oder Kongruenzgeometrie kann als Transformationsgruppe der Bewegungen (Translationen, Drehungen, Spiegelungen und zusätzlich Schraubungen im Raum) gekennzeichnet werden, die alle längen- und winkeltreue Transformationen sind. Bei der Ähnlichkeitstransformation verzichtet man auf die Längentreue und lässt Punktstreckungen zu. Wird zusätzlich auf die Winkeltreue verzichtet, so gelangt man zu den affinen Transformationen, die die Parallelität erhalten, aber keine Längen und Winkel. Die Perspektivtransformation bzw. Projektive Transformation erhält nur noch die Kollinearität. Bei der topologischen Transformation bleiben schließlich nur Nachbarschaften erhalten.

Durch diese Entwicklung der Geometrie zu einer Transformationsgeometrie wurde der Symmetriebegriff auf eine neue Grundlage gestellt und wesentlich erweitert. Damit wird schon die Bedeutung der geometrischen Transformation für die Gestaltung deutlich. Symmetrie war seit der Antike grundlegender Begriff für die Gestaltung. Die geometrischen Transformationen sollen im Folgenden anhand von Beispielen mit Entwurfsprozessen verbunden werden. 


\section{Beispiele geometrischer Transformationen in Gestaltungsprozessen Projektion - Umrissfigur - Komposition}

Die erläuterte Herkunft des Abbildungs- bzw. Transformationsbegriffs von der Vorstellung, ein Bild eines räumlichen Objektes durch die Projektion auf eine Bildebene zu erzeugen, soll im ersten Beispiel Anwendung finden. Für den Zusammenhang von räumlichem Objekt und Bild des Objektes ist es wesentlich, die Transformation der Projektion in beide Richtungen zu betrachten. Von jedem 3D-Objekt gibt es zwar ein eindeutiges 2D-Bild, aber in der Umkehrung gibt es unendlich viele 3D-Objekte zu einem 2D-Bild, die Transformation der Projektion ist nicht umkehrbar eindeutig. Ein räumliches Objekt wird mittels Normalprojektion auf eine horizontale Ebene projiziert. Werden nur die äußersten Linien, die Berührpunkte mit dem Projektionszylinder, festgehalten, so entsteht die Umrissfigur. Ausgangspunkt in dem Beispiel in fig. 5 war die Umrissfigur des Hauses M. Visser in Bergeijk, Niederlande, 1955-56 von Gerrit Rietveld entworfen und in den Jahren 1967-69 von Aldo van Eyck umgeplant. Die Studierenden erhielten diese Information erst nach ihrer Bearbeitung. Sie entwickelten aus der Umrissfigur eine räumliche Komposition. Durch diese Umkehrung der Transformation, vom Bild bzw. Umrissfigur zum räumlichen Objekt, wird die Vieldeutigkeit dieser umgekehrten Transformation im kreativen Prozess erlebbar gemacht. Diese Aufgabe war das Einstiegsbeispiel für Architekturstudierende im I. Semester (fig. 5).

Fig. 5. Räumliche Komposition aus einer Umrissfigur - Modelle von Architekturstudierenden 2018.

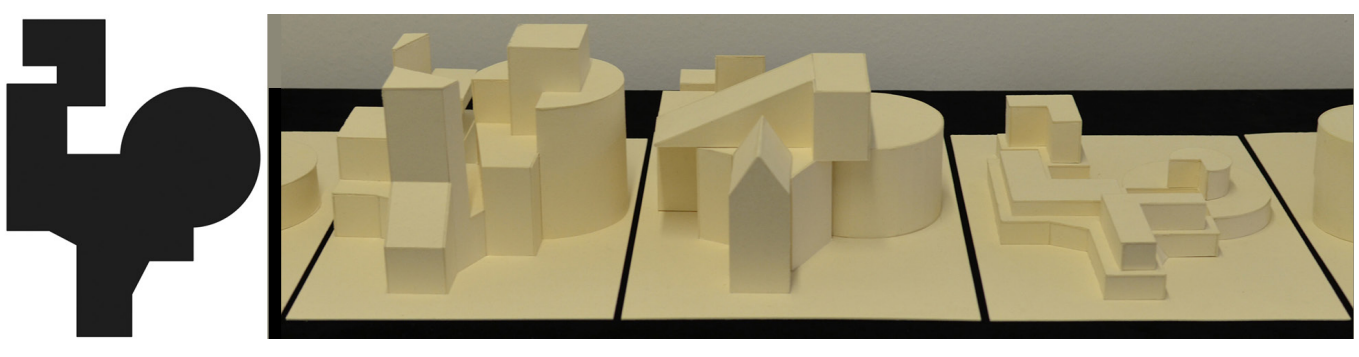

\section{Kongruenztransformationen}

Mittels Kongruenztransformationen können sowohl in der Ebene als auch im Raum Muster bzw. Kompositionen entwickelt werden. Durch Anordnungen von Grundelementen durch Translation, Spiegelung und Rotation können räumliche Strukturen wie in fig. 6 entstehen. Der Student Falk Ahlhelm setzte sich im Kurs zur Gestaltungsgeometrie mit Methoden der Strukturbildung auseinander.

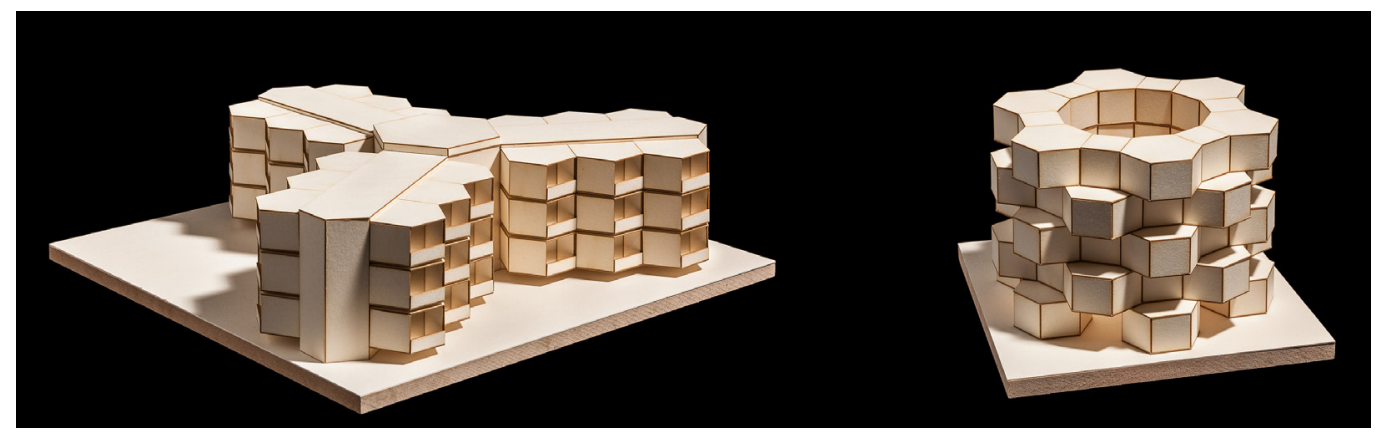

Fig. 6. Strukturbildung durch Kongruenztransformatione am Beispiel von sechseck gen Modulen sowie Kombination von Sechseck und Quadrat durch Extrusion, Stapelung, Verschiebung Drehung und Spiegelung von FalkAhlhelm, 2017. Fotos (c) Bernhard Friese. 

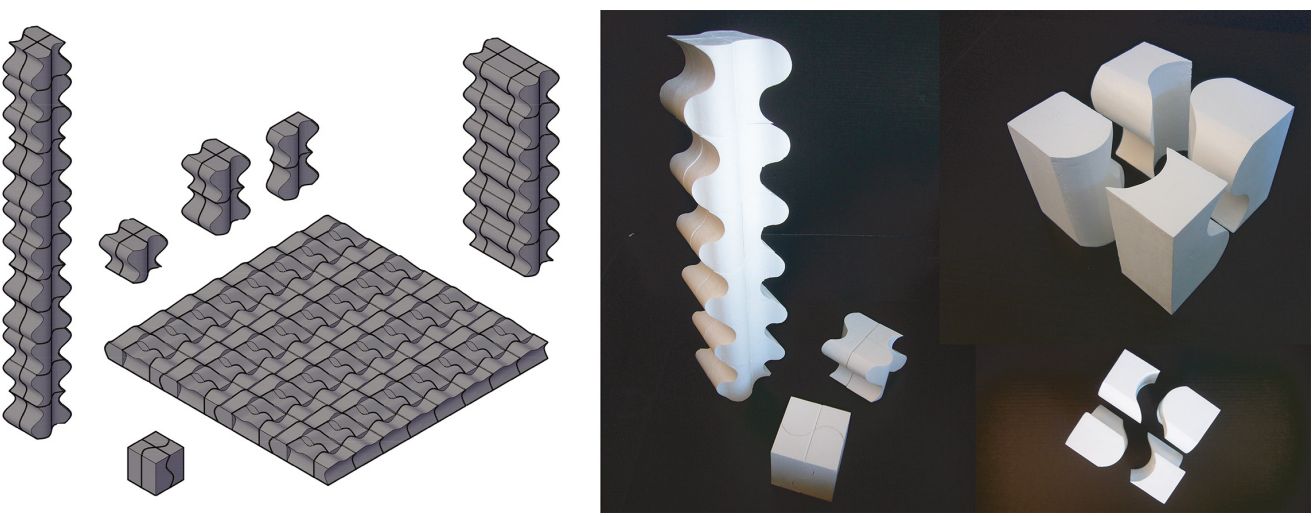

\section{Ähnlichkeit und Selbstähnlichkeit}

Ähnlichkeit als Transformationsprinzip erhält Proportionen und Winkel, nicht aber Längen. Eine Form bzw. Struktur wird skaliert wiederholt, wie Roland Knauer dieses Prinzip auch in seinen Gitterbildungen anwendet (fig. 3, 2). Eine besondere Form der Ähnlichkeit ist die Selbstähnlichkeit, die zu Fraktalen Strukturen führt. Fig. 8 zeigt ein Projekt von Viyaleta Zhurava. Ein Grundelement, vierWohnungen in Quaderform werden durch eine umlaufende Treppe erschlossen, bilden eine spiralähnliche Struktur, die wiederum in einen Quader eingefügt werden kann. Das linke Beispiel in fig. 8 zeigt eine Gebäudegruppe aus vier einzelstehenden Bauten, die sich voneinander unterscheiden, aber zusammen eine Gesamtansicht bilden, die von allen Seiten wie die Hauptfigur aussieht. Das zweite Konzept rechts ist eine fraktale Megastruktur.
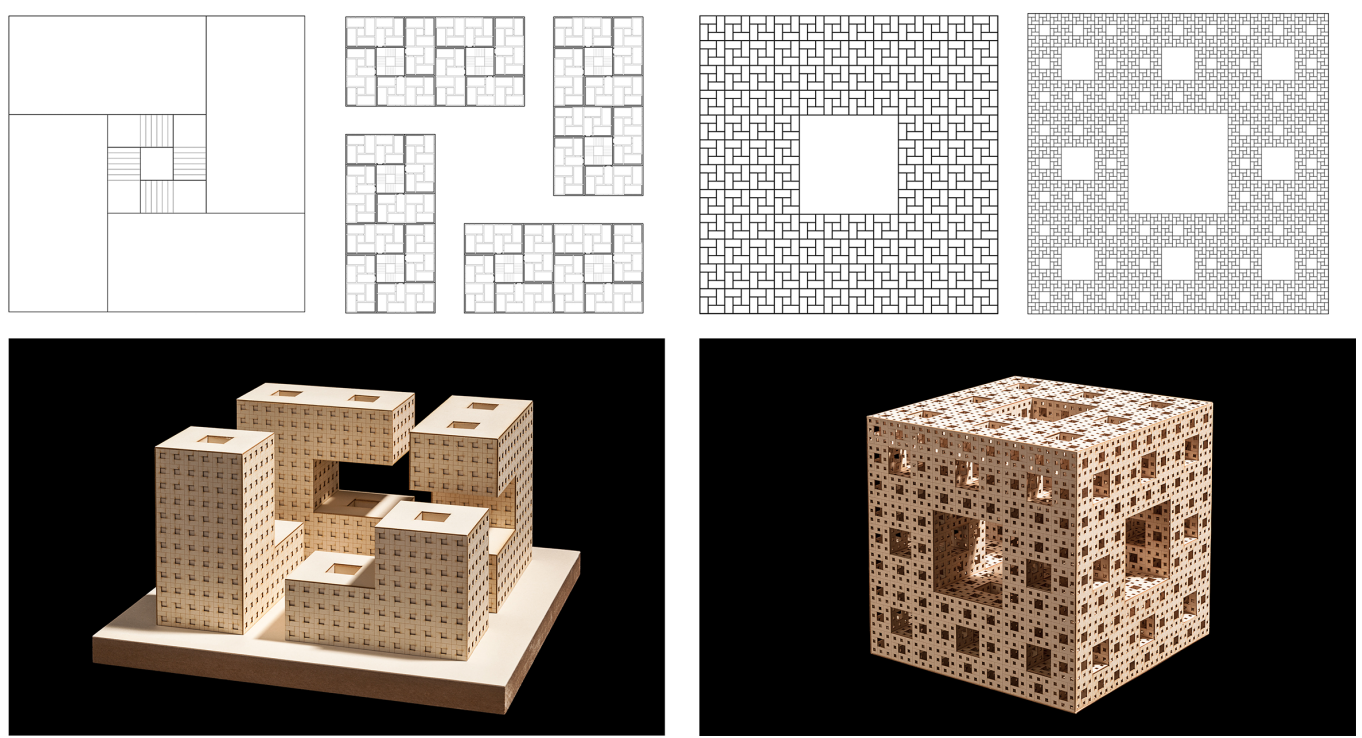
Fig. 9. Affine Transformation der Kuppel des Pantheons zum Ellipsoid von Viyaleta Zhurava, 2017.

\section{Affinität}

Die Affinität erhält nur noch die Parallelität. Die durch Parallelprojektion erhaltenen Figuren sind affin zu den Ausgangsfiguren, z.B. Rechteck wird zum Parallelogramm, Kreis wird zur Ellipse. Eine Anwendung affiner Transformationen im architektonischen Entwurf schlug bereits Juan Caramuel de Lobkowitz in Architectura civil recta y obliqua 1678 vor, um ein Gebäude oder ein Detail an die natürlichen Strukturen des Ortes anzupassen. Seine Zeichnungen zeigen stets die affine Transformation ebener Figuren, obwohl stets eine Transformation der räumlichen Form gemeint ist, wie z.B. Geländer-Details von Treppen. Die Studentin Viyaleta Zhurava untersuchte die affine Transformation der Kuppel des Pantheons, die dann zum Ellipsoid wird (fig. 9).

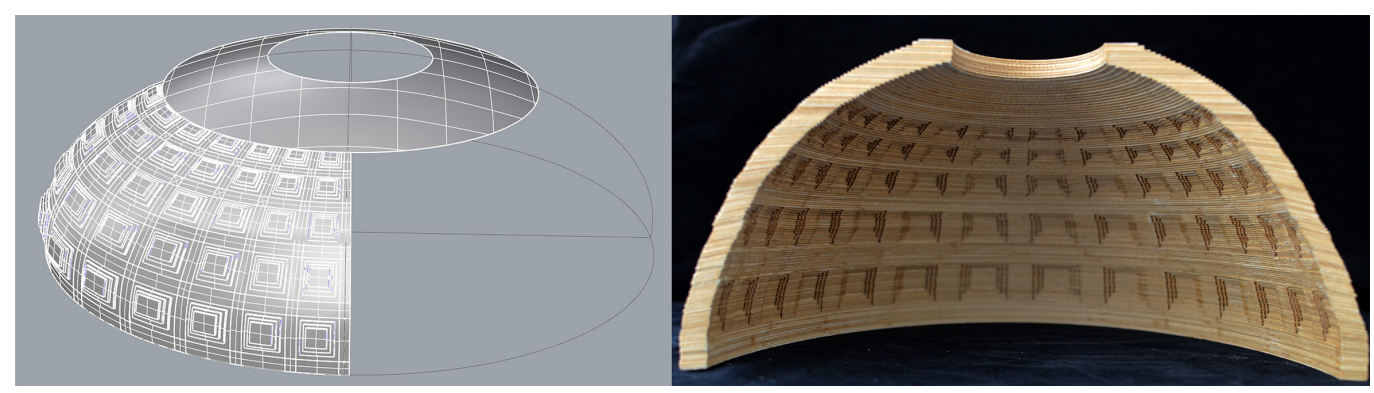

\section{Perspektivische Transformation - Reliefperspektive}

Die perspektivische Transformation, auch projektive Transformation genannt, führt schließlich zur Beziehung der Kollineation von Figur und Bildfigur, d.h. Punkte auf einer Geraden bleiben kollinear, das Doppelverhältnis bleibt erhalten, aber nicht das Teilverhältnis.

Durch die Abbildung der Zentralprojektion entsteht das perspektivische Bild einer Figur. Wird diese perspektivische Transformation auf ein räumliches Objekt angewandt, so entsteht eine Reliefperspektive des räumlichen Objektes. Durch die Einführung der Projektiven Geometrie wurde das geometrische Verständnis dieser Transformation erst möglich [Leopold 2019]. Das durch die perspektivische Transformation erhaltene Objekt ist auf einen Blickpunkt, das Projektionszentrum bezogen, ermöglicht also die Wahrnehmung in den Entwurf miteinzubeziehen (fig. I0).
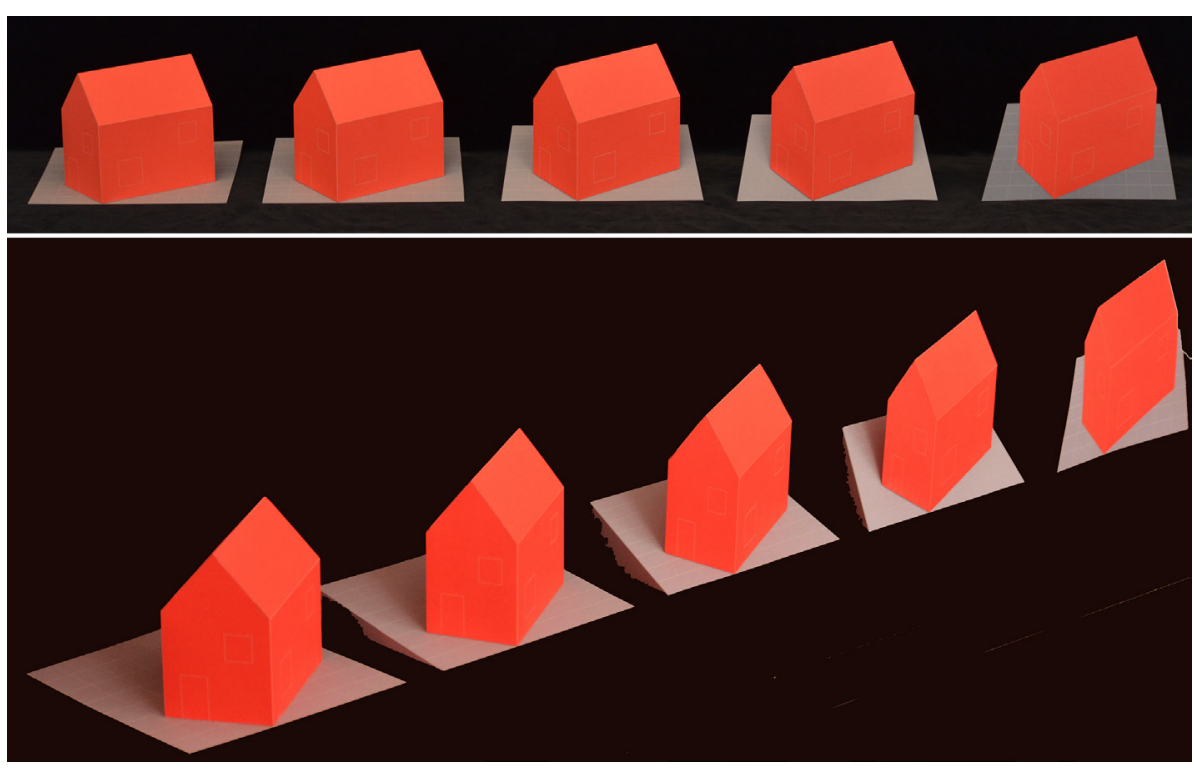
Topologische Transformation - Metamorphose

Die topologische Transformation erhält keine Formeigenschaften, sondern nur Zusammenhangsverhältnisse, also Nachbarschaften. Der Student Tom Forster verwendete topologische Transformationen bei der Formmetamorphose seines Turmquerschnittes vom Dreipass zum Dreieck. Sein Projekt war im Rahmen eines Seminars über regelbasiertes Entwerfen in der Gotik vom gotischen Formenrepertoire inspiriert (fig. I I).
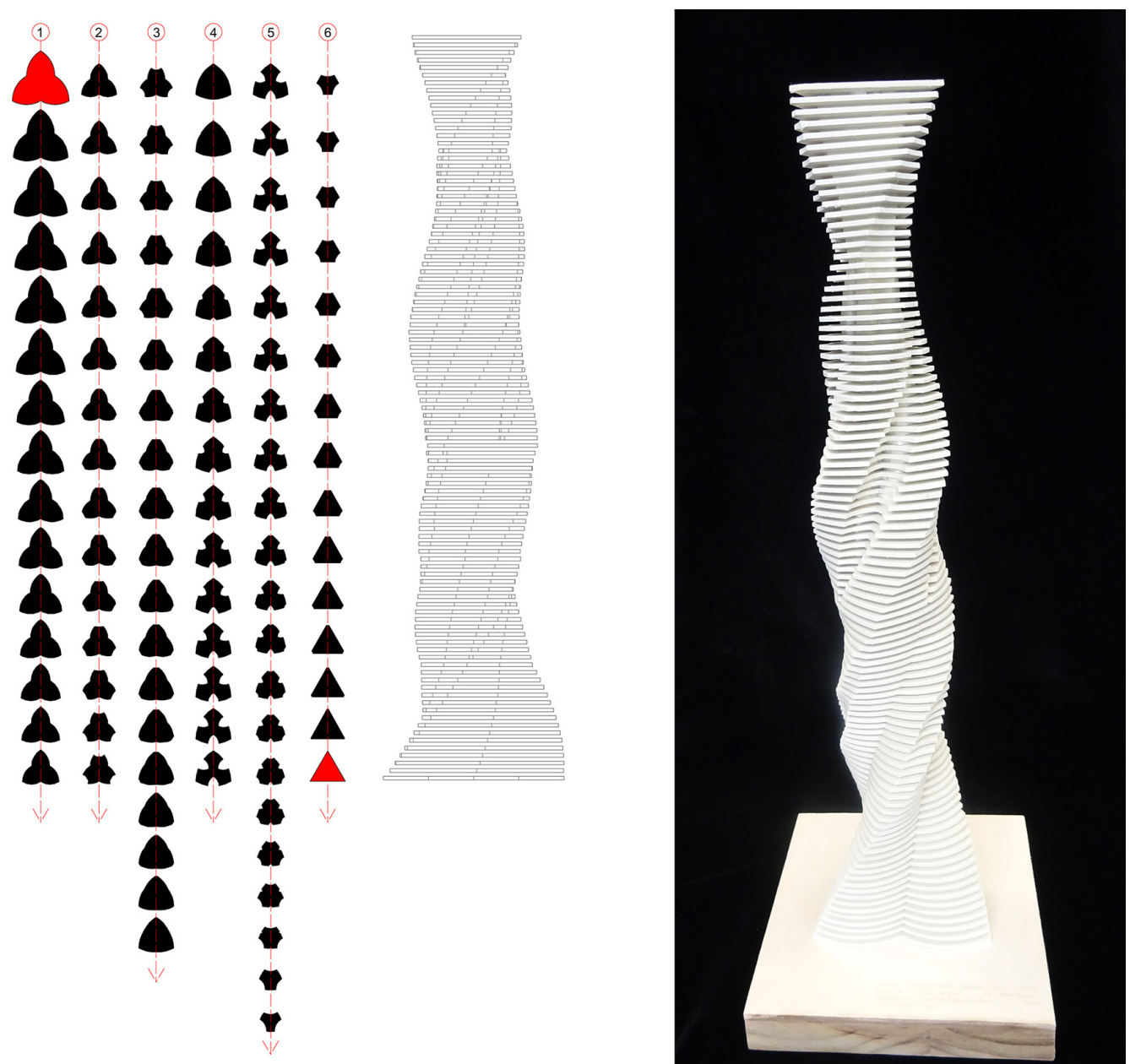

Zusammenfassung und Ausblick

Der Ursprung des Begriffs der Transformation kann in der Generierung von Form und Wachstumsprozessen in der Natur gesehen werden. Er ist damit verbunden mit der Morphologie und Metamorphose. Dem kreativen Denken kann das Phänomen der Transformation wichtige Impulse geben, und es ist damit für eine Methodik der Gestaltung und des Architekturentwurfs einsetzbar. Die Geometrie wurde durch die Betrachtung von Transformationen und ihrer Invarianten revolutioniert. Der Versuch, geometrische Transformationen für Gestaltungsprozesse nutzbar zu machen, wurde an einigen Beispielen ansatzweise aufgezeigt. Wie geometrisch strukturelles Denken in Transformationen zu einer Methodik des Entwerfens beitragen kann, bleibt ein spannendes Forschungsfeld zwischen den Gestaltungsdisziplinen und der Geometrie. 


\section{Bibliografie}

Durand Jean-Nicolas-Louis ( I 802). Précis des leçons d'architecture données à l'École Polytechnique. Vol. I. Paris: Bernard. <http:// mdz-nbn-resolving.de/urn:nbn:de: bvb:| 2-bsb |087|455-0>.

Goethe Johann Wolfgang (20 I4). Schriften zur Morphologie. Berlin: Holzinger. (Originale Schriften zur Morphologie, I8I 7 ).

Klein Felix (1872). Vergleichende Betrachtungen über neuere geometrische Forschungen. Erlangen: Deichert. <http://www. deutschestextarchiv.de/book/view/klein_geometrische_|872>.

Knauer Roland (2008). Transformation. Grundlagen und Methodik des Gestaltens. Basel: Birkhäuser.

Leopold Cornelie (2019). The Development of the Geometric Concept of Relief Perspective. In Nexus Network Journal, 2 I/2, 2019, pp. 227-252

Lobkowitz Juan Caramuel de (1678). Architectura civil recta y obliqua. En Vegeven: En la emprenta obispal por Camillo Corrado, | 678. <https://archive.org/details/architecturacivi00cara>

March Lionel, Steadman Philip (1974). The Geometry of Environment. Cambridge, Mass.:The MIT Press (First published London: RIBA Publications Limited, 1971)

Müller Emil (1913). Das Abbildungsprinzip. Jahresbericht der deutschen Mathematiker-Vereinigung 22/1913 Leipzig, pp 44-59. <https://www.deutsche-digitale-bibliothek.de/item/IDJMAWZO6S4ITCKBNVS62PIUPTE4ZKAD>.

Noebel Walter A. (ed.). (1982). Oswald Mathias Ungers. Die Thematisierung der Architektur. Neuauflage Zürich:Verlag Niggli.

Thompson D'Arcy Wentworth (2006). Über Wachstum und Form. Frankfurt a.M.: Eichborn. (Original: On Growth and Form. Cambridge: University Press, 1961).

\section{Autor}

Cornelie Leopold,TU Kaiserslautern, Germany, cornelie.leopold@architektur.uni-kl.de

To cite this chapter. Cornelie Leopold (2020). Geometrische Transformationen als Entwurfsmethodik/Geometric transformations as design methodology. In Arena A., Arena M., Brandolino R.G., Colistra D., Ginex G., Mediati D., Nucifora S., Raffa P. (a cura di). Connettere. Un disegno per annodare e tessere. Atti del $42^{\circ}$ Convegno Internazionale dei Docenti delle Discipline della Rappresentazione/Connecting. Drawing for weaving relationships. Proceedings of the 42th International Conference of Representation Disciplines Teachers. Milano: FrancoAngeli, pp. I 221- 1240. 


\section{Geometric Transformations as Design Methodology}

Cornelie Leopold

\section{Abstract}

Transformation, Latin transformare means to reshape, is a central concept in architectural design. The concept of transformation became fundamental in geometry and mathematics. Transformation is associated with the idea of morphology and metamorphosis, which play a role in the description of growth processes. The architectural and the geometric concept of transformation will be examined in more detail and its role for a methodology of architectural design will be analyzed. As examples, a look at the design methods of Jean-Nicolas-Louis Durand, Oswald Mathias Ungers and Roland Knauer, in which transformations are used, will be taken.

The mathematical-geometric concept of transformation has given rise to a new way of thinking, by which mappings and transformations are structured according to their invariants. The invariants of the relevant transformations are those properties of geometric objects that remain unchanged when the relevant transformations are applied. With this point of view, Felix Klein restructured the geometries in his Erlangen Program in 1872.

How this approach can also be used in architectural design methodology will be explained in the further course by some examples from students of architecture. The transformations are structured geometrically and shown in their usability for architectural design processes.

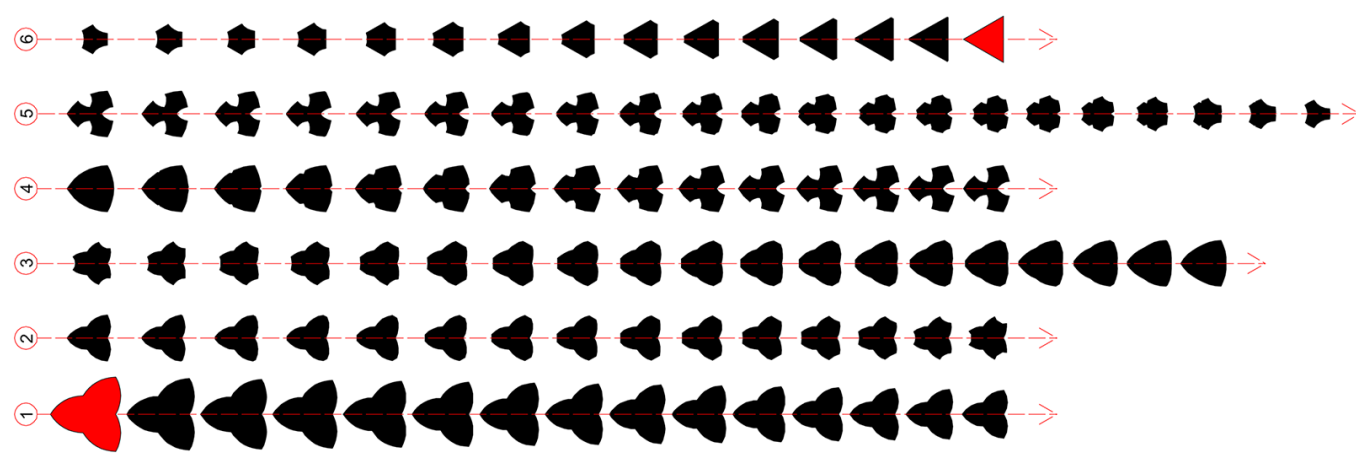




\section{Concept of Transformation}

Transformation is defined as the process of reshaping, converting, redesigning and thus changing from one state to another. In nature, transformation is a perpetual process, for example the conversion from a seed to a plant, or alternatively, when nature changes through the course of seasons. Transformation, therefore, is also related to morphology, the study of shape. This term was first used by Johann Wolfgang von Goethe especially in the field of botany [Goethe, 1817, p. 6]. He saw the complexity of organic bodies as a specific metamorphosis, hence a conversion or transformation of a simple form. These ideas can be applied to architectural design and thereby become effective in design processes. D'Arcy Wentworth Thompson analyses the relation between growth processes and form in his book On Growth and Form published in 1917. In particular, his theory of transformation shows a correlation between physical forces and mathematical form or change of form. He considers transformation to be connected with the emergence and development of form or the conversion of one form into another [Thompson 1917, pp. 379f.]. This means that the concept of transformation already implies an application in design methodology.

\section{Transformation in Architectural Design Methodology}

In Die Thematisierung der Architektur, Oswald Mathias Ungers refers to the "subject of transformation or the morphology of form": "All incidents, both natural and man-made, more or less follow the laws of formation and transformation. The two processes are mutually dependent [...] In this context, the phenomenon of transformation can trigger significant stimuli for the creative thinking, because it teaches not only thinking in opposites and alternatives, but above all in complex contexts" [Noebel, 20 I I, p. 19, translated from German to English by B. Blumenröder].

He attributes a creative principle to transformation. He sees morphological transformation as a means of design. Starting from three basic geometric shapes, square, triangle and circle Ungers designs an unfinished morphological shape dictionary. He builds on the theory and work of Jean-Nicolas-Louis Durand's Précis des Leçons d'Architecture, I 802. Durand also proceeds from the basic forms of square and circle (fig. I) and develops a design theory by the means of divisions and combinations.

Fig. I. Ensemble of buildings as results from the subdivision of squares, parallelograms and their combination with circles

[Durand I802, Planche 20, pp. 253, 254].

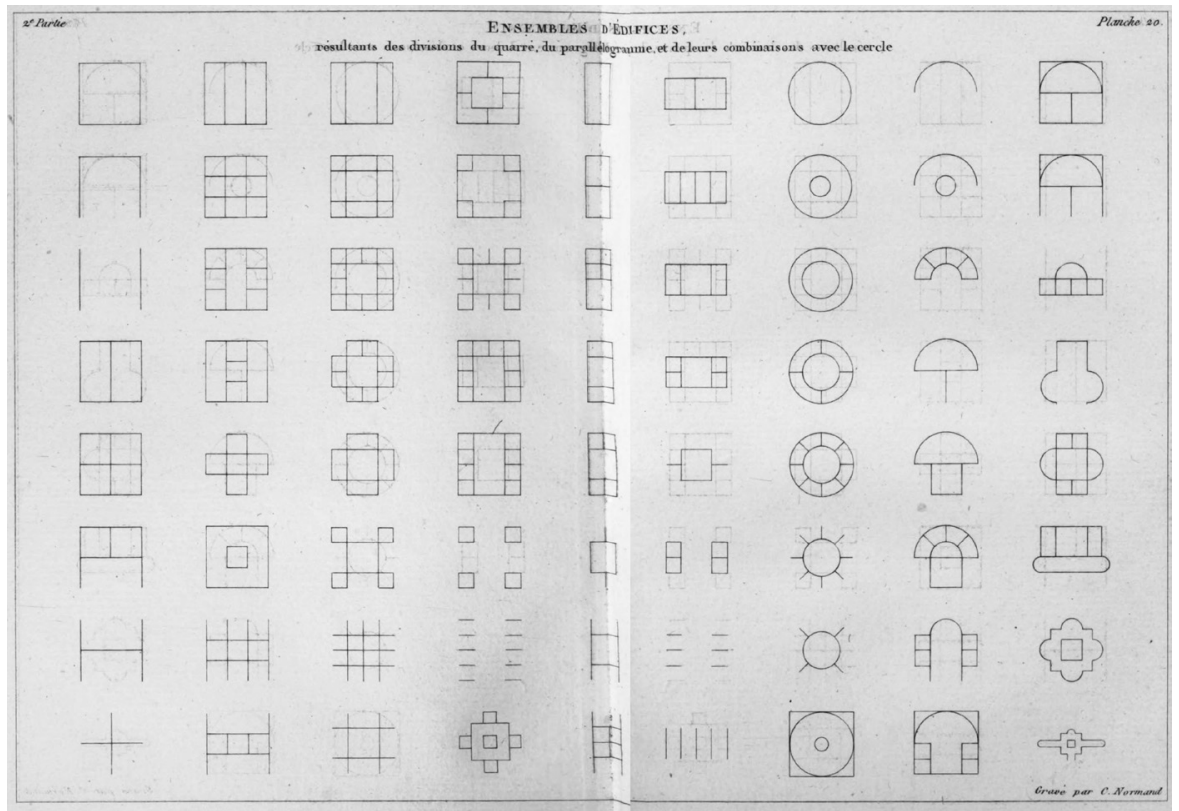


He adds that on Table (Planche) 20 the focus should be on the principle of subdivision. The different horizontal arrangements should also be imagined vertically in space, because it is not possible to fully represent the large number of possible combinations.

Ungers has taken up and continued his approach from Durand. With his design for the student dormitory Enschede in Holland from 1963, Ungers applies the methods of his morphological shape dictionary. He describes the transformations used on the three basic forms as refraction, diffraction, division, inversion, duplication, reflection, succession, repetition, superimposition etc. He aims to apply these transformations not only to the basic forms themselves, but also to their spatial capacity. Due to the possible variety, Ungers gave up this theoretical approach of an encyclopaedia of spatial and body shapes. However, he considers the procedure by transformation to be successful in specific design situations.

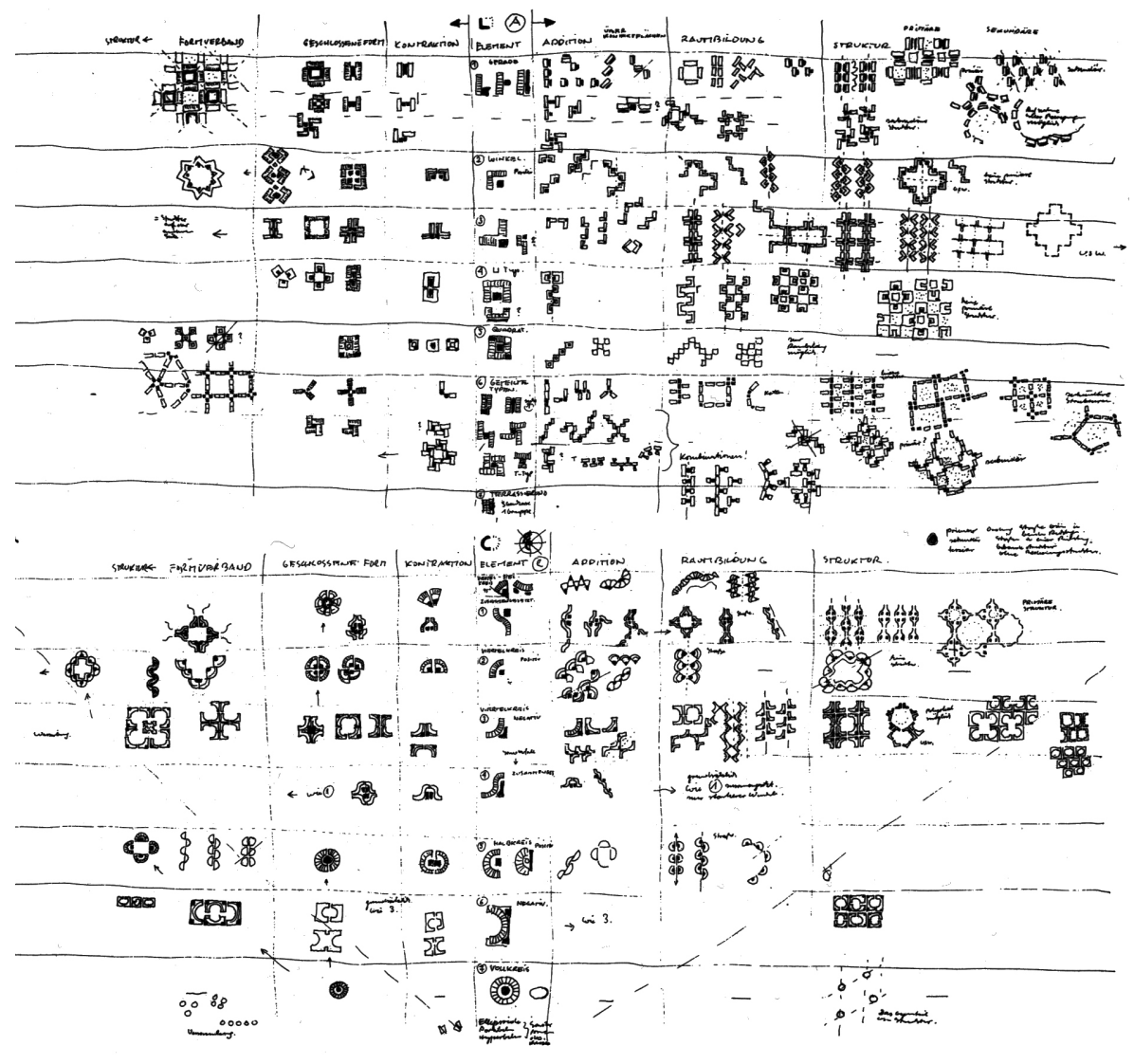

Ungers divides his dictionary of morphological form (fig. 2) into the following columns: structure, form association, closed form, construction, element, addition, spatial formation, structure. By doing this, he develops complex structures from the basic shape or basic structure, using the mentioned processes and criteria.

Roland Knauer, professor at the University of Design in Schwäbisch Gmünd, Germany, established a design method based on the concept of transformation. He starts with the forms and structures of a basic repertoire, point, line, rod, surface, and solid, which then become a design in the aesthetic process through a grammar of transformation. He considers every complex shape to be a variation of these basic elements. Consequently, he conceptualizes these basic elements as spatial and not as flat geometric figures like that of Durand and Ungers, although they refer to the spatial interpretation as well.

Knauer starts with the element rod which converts depending on changes in cross-sections, axis positions, curvatures, torsions, volumes. Different connection options arise from ar- 
rangements and relations of positions. Knauer then continues the design path via possible grids towards the formation of solids (fig. 3). Spatial tessellations are a model for assembling solids into a more complex ensemble. Solid divisions combined with operations such as subtraction and addition as well as transformations of the partial solids create a variety of new compositions.

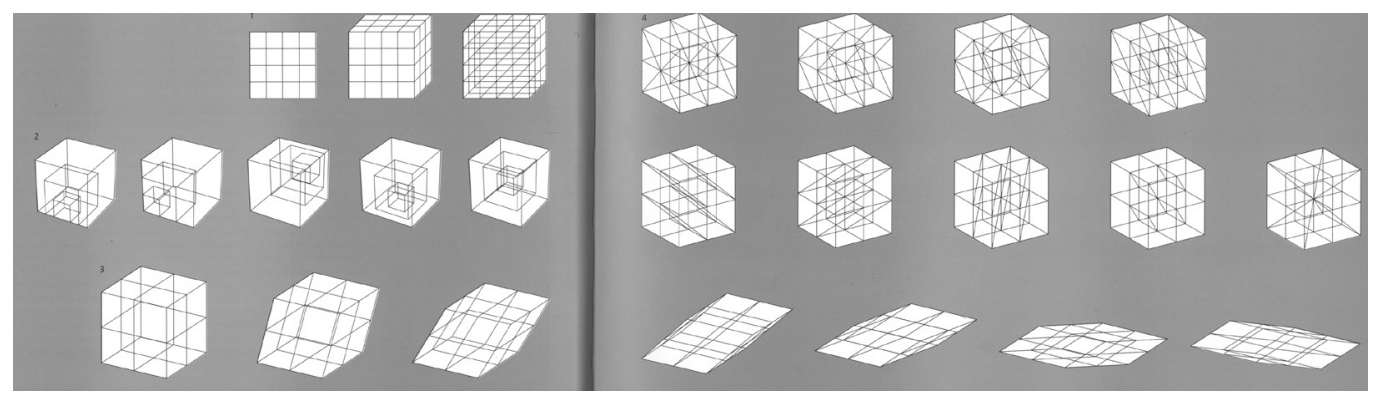

\section{Geometric Concept of Transformation}

The mathematical concept of transformation is closely related to the concept of mapping, meaning function, which is used in a diversity of contexts. In the context of set theory, it becomes the essential basis with universal application: each element $x$ of a set $X$ is associated with a unique element $y$ of a set $Y$. Here, the element $y$ is then also termed as the image of $x$ based on the mapping used. The underlying concept explicitly relates to the geometric understanding of the creation of an image of a spatial object and thus to the projection as the basic concept of descriptive geometry. In his inaugural address as rector of the Vienna University of Technology in 1912, Emil Müller described the principle of mapping as a research principle that "actually dominates all our thinking and research" [Müller 1913, p. 45, translated by B. Blumenröder] in mathematics and its fields of application, but also far beyond mathematics.

If two geometrical figures are mapped onto one another, they are geometrical related. Such relations are congruence, similarity, affinity and collineation. These geometric relations can be found both in plane and in space or more generally, in mathematical spaces. Then, those properties of the figures are considered, which remain unchanged, i.e. invariant when being mapped. It was Felix Klein's [Klein 1872] achievement to classify the different geometries based on the invariants of the respective mapping or transformation. Klein uses the notion of transformation. Previously, August Ferdinand Möbius has already addressed the relation of geometric figures in his work Der barycentrische Calcul, published in 1827. He structures these relations into equality (congruence), similarity and collineation. In his Erlanger Programm, Felix Klein links the geometry or geometries with the concept of transformation and puts them on a new basis with the notion of groups, which originally had been developed in the area of algebra. Geometry is understood as the discipline that examines the properties of figures that remain unchanged during a change in position, i.e. the invariants of the transformation. He therefore uses a classification of the respectively approved geometric transformations. The transformations belonging to a geometry form a group in terms of their successive execution, the so-called transformation group of the geometry. The properties examined in the relevant geometry remain invariant with respect to all transformations of the transformation group. Thus, the transformation itself becomes the basic element of geometry and no longer the geometric figures. In addition, topology can be added as geometry, with only the neighbourhood, i.e., connectedness as an invariant. In the table in fig. 4, March and Steadman have identified each transformation by the corresponding invariants. 
Fig. 4. Classification of the different geometries according to the transformations and their invariants according to March, Steadman 1974 p. 27].

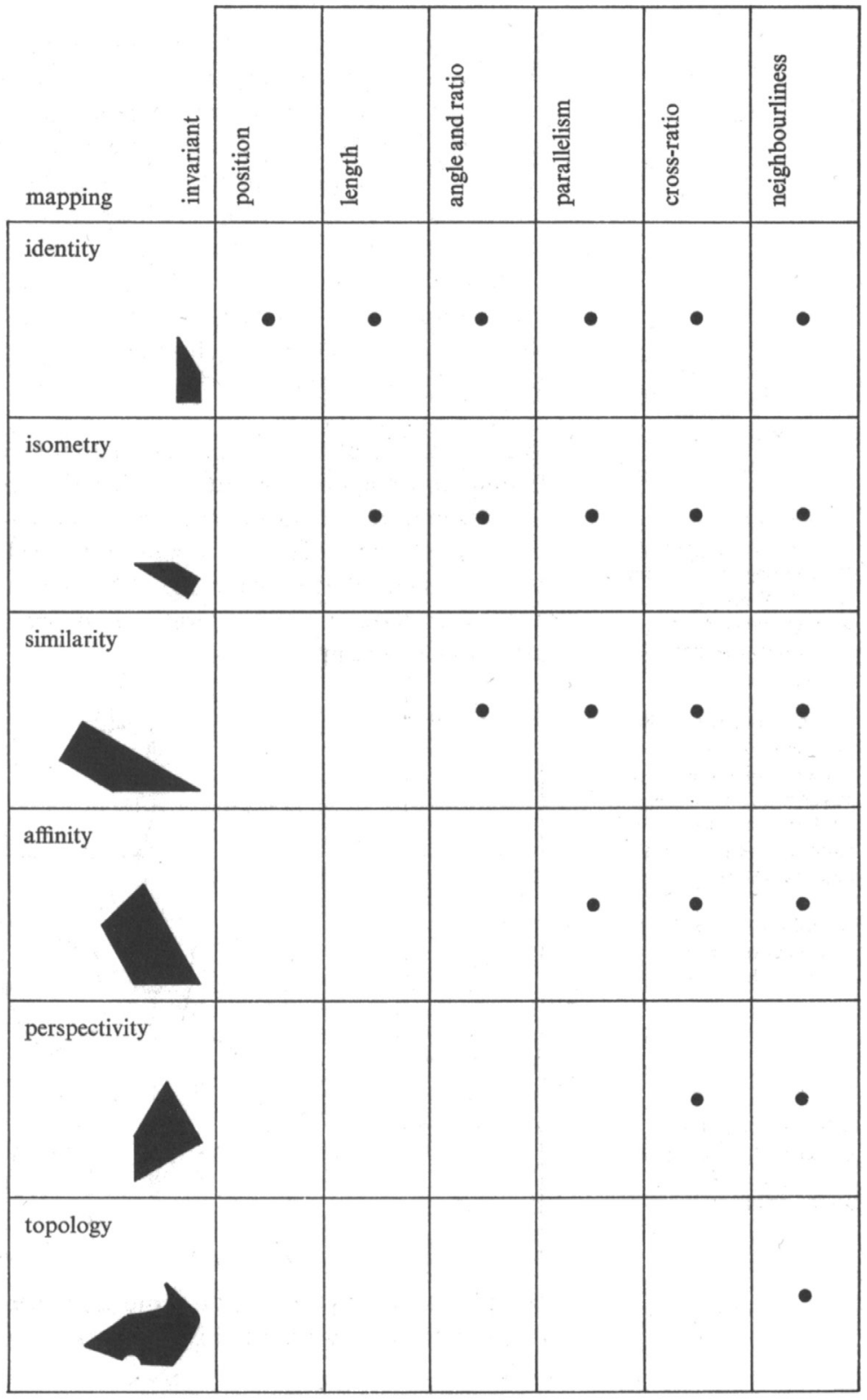

The elementary Euclidean plane or spatial geometry or congruence geometry can be characterized as a transformation group of motions (translations, rotations, reflections and additional helical rotation in space), which are all isometric and conformal transformations. Similarity transformations are not isometric and allow uniform scaling. Non-conformal transformations that maintain parallelism, but no lengths and angles, are called affine transformations. The perspective transformation or projective transformation only maintains collinearity. Ultimately, only neighbourhoods remain in the topological transformation.

As geometry evolved into transformation geometry, the concept of symmetry was put on a new basis and significantly expanded. This reinforces the importance of the geometric transformation for the design. Since antiquity, symmetry has been a basic concept for design. In the following part, the geometric transformations are to be combined by means of examples from design processes. 


\section{Examples of Geometric Transformations in Design Processes Projection - Contour - Composition}

The origin of the term of mapping or transformation from the conception of creating an image of a spatial object by projecting it onto an image plane is to be used in the first example. It is of elementary importance to consider the transformation of the projection in both directions for the connection between the spatial object and the image of the object. There is a unique 2D image of every 3D object, but conversely there is an infinite number of 3D objects related to a 2D image; the transformation of projection is non-injective, only surjective. A spatial object is projected onto a horizontal plane by means of a normal projection. The contour is created if only the outer lines, the points of contact with the projection cylinder, are held. The example in fig. 5 is based on the contour of the M.Visser house in Bergeijk, the Netherlands, designed by Gerrit Rietveld in 1955-56 and redesigned by Aldo van Eyck in 1967-69. The students received this information only after they had completed the assignment. They developed a spatial composition from the contour. The ambiguity of this reversed transformation can be seen in the creative process of reversing the transformation from the image or contour to the spatial object. This assignment was a starting example for architecture students in the first semester (fig. 5).

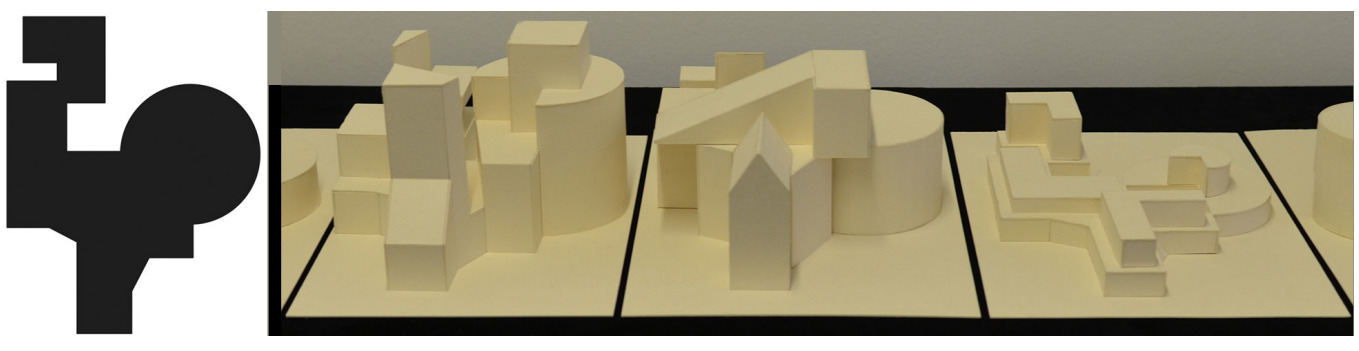

\section{Congruence Transformations}

Congruence transformations can be used to develop patterns or compositions both on the plane and in space. Spatial structures as in fig. 6 can arise by arranging basic elements using translation, reflection and rotation. The student Falk Ahlhelm, focused on the methods of structure formation in the course of design geometry.

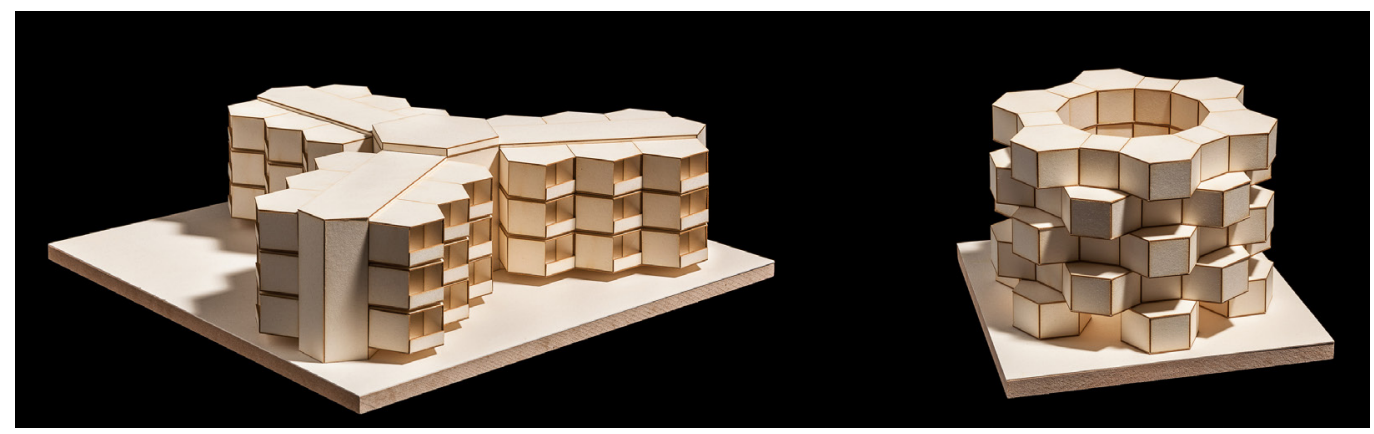



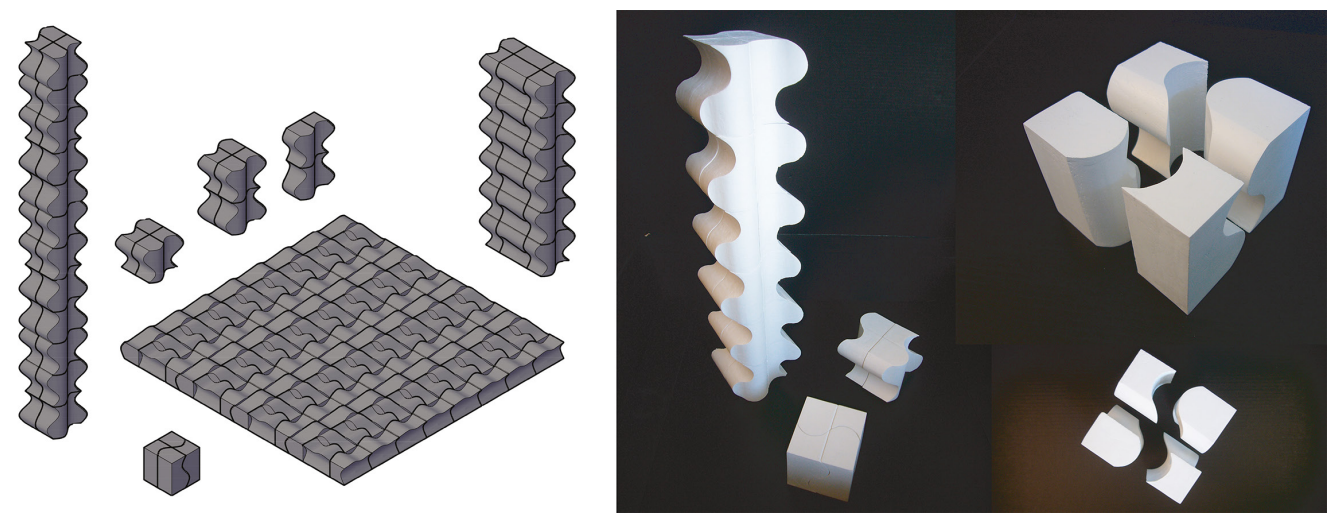

\section{Similarity and Self-Similarity}

Similarity as a principle of transformation retains proportions and angles, but not lengths. $A$ form or structure is repeated after being scaled. Roland Knauer uses this principle in his grid formations (figs. 3, 2). A special form of similarity is the self-similarity, which leads to fractal structures. Fig. 8 shows a project by Viyaleta Zhurava. A base element, four apartments in the shape of a cuboid are accessed by a circular staircase. They form a spiral-like structure that again can be inserted into a cuboid. The left example in fig. 8 shows a group of buildings consisting of four detached buildings which differ from each other. All together, they form a total view which looks like the main shape from all sides. The second concept on the right is a fractal mega structure.
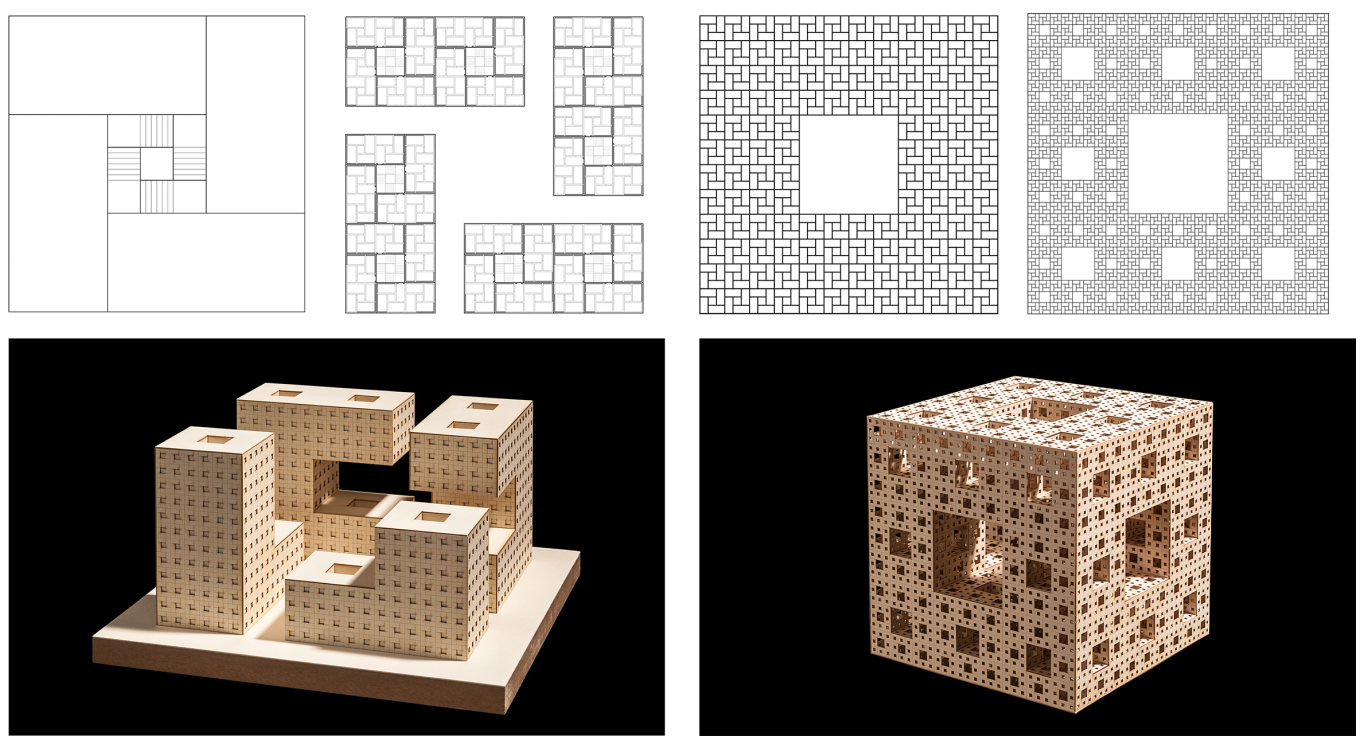


\section{Affinity}

The affinity only retains parallelism. The figures obtained by parallel projection are affine to the original shapes, e.g. a rectangle becomes a parallelogram, a circle becomes an ellipse. In his Architectura civil recta y obliqua published in 1678, Juan Caramuel de Lobkowitz proposed using affine transformations in architectural design in order to adapt a building or a detail to the natural structures of the site. His drawings show the affine transformation of flat figures, although it always implies a transformation of the spatial form, e.g. railing details of stairs. The student Viyaleta Zhurava examined the affine transformation of the cupola of the pantheon, which then becomes an ellipsoid (fig. 9).

Fig. 9. Affine transformation of the cupola of the pantheon to the ellipsoid by Viyaleta Zhurava, 2017.
Fig. 10. Relief perspective of a house in different Roth, 2019

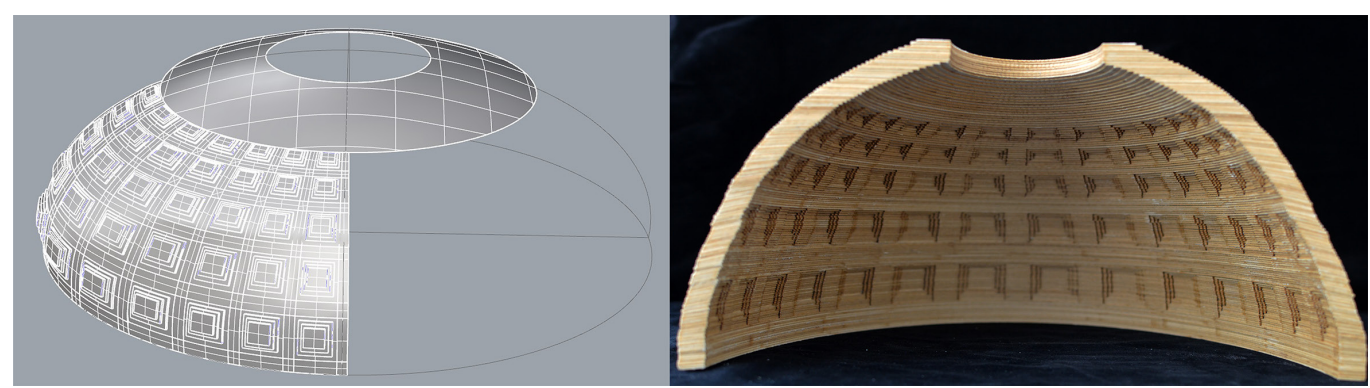

\section{Perspective Transformation - Relief Perspective}

The perspective transformation, also known as projective transformation, finally leads to the relation between the collineation of figure and image figure, i.e. points on a straight line remain collinear, the cross-ratio is retained, but not the splitting ratio.

Central projection leads to the perspective image of a figure. If this perspective transformation is applied to a spatial object, a relief perspective of the spatial object is created.The introduction of the projective geometry enabled the geometric understanding of this transformation. The object obtained through perspective transformation is related to a point of view, the projection centre, thus allowing perception to be included in the design (fig. I0).
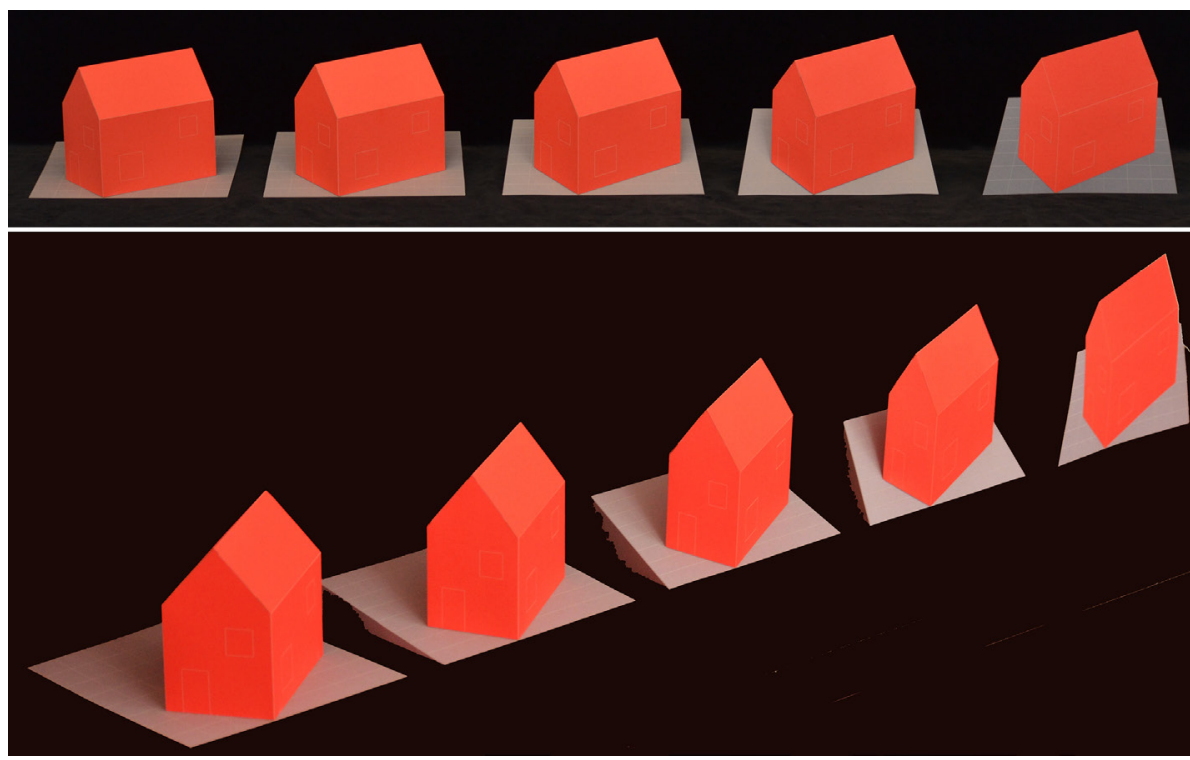


\section{Topological Transformation - Metamorphosis}

The topological transformation does not retain any shape properties, but only correlations, i.e., neighbourhoods. The student Tom Forster used topological transformations in the shape metamorphosis from a trefoil to a triangle as the cross-section of a tower. His project was inspired by the Gothic repertoire of forms as part of a seminar on rule-based design in Gothic (fig. I I).

Fig. II. Form metamorphosis from a lying sections rotated and stacked on top of each other create the tower by Tom Forster, 2018
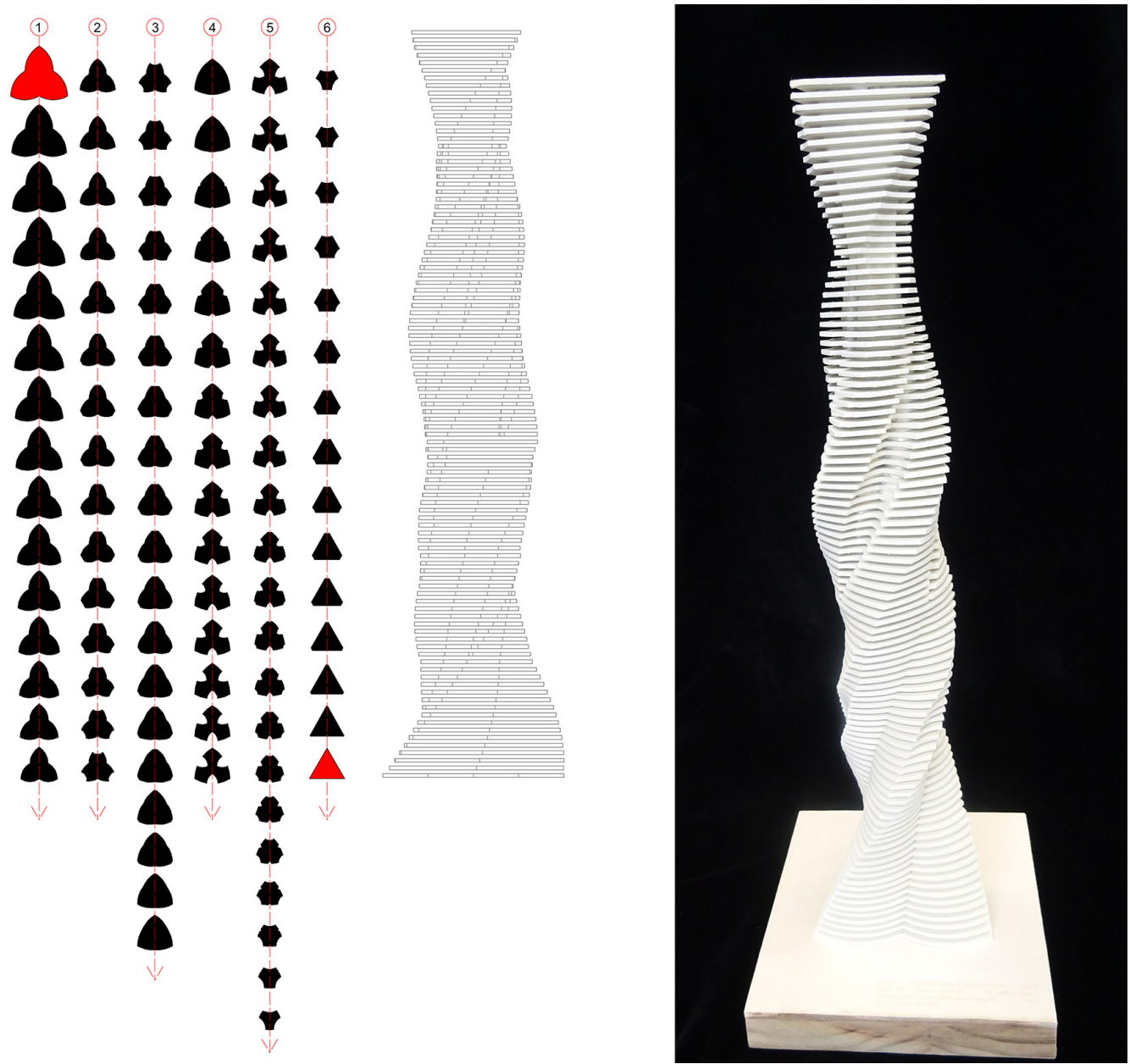

\section{Summary and Outlook}

The origin of the concept of transformation can be seen in the creation of form and growth processes in nature. Thus, it is associated with morphology and metamorphosis. The phenomenon of transformation can give important impulses to creative thinking and can therefore be used for a methodology of design e.g. in architecture. Geometry was revolutionized by looking at transformations and their invariants. Some examples show the attempt to make geometric transformations usable for design processes. This remains an exciting field of research between the design disciplines and geometry to explore how geometric structural thinking in transformations can contribute to a methodology of design.

\section{Acknowledgement}

Many thanks to Benedikt Blumenröder for translating the German text into English and to the students for their committed projects. 


\section{References}

Durand Jean-Nicolas-Louis ( I 802). Précis des leçons d'architecture données à l'École Polytechnique. Vol. I. Paris: Bernard. <http:// mdz-nbn-resolving.de/urn:nbn:de: bvb: | 2-bsb |087|455-0>.

Goethe Johann Wolfgang (20 I4). Schriften zur Morphologie. Berlin: Holzinger. (Originale Schriften zur Morphologie, I8I 7 ).

Klein Felix (1872). Vergleichende Betrachtungen über neuere geometrische Forschungen. Erlangen: Deichert. <http://www. deutschestextarchiv.de/book/view/klein_geometrische_|872>.

Knauer Roland (2008). Transformation. Grundlagen und Methodik des Gestaltens. Basel: Birkhäuser.

Leopold Cornelie (2019). The Development of the Geometric Concept of Relief Perspective. In Nexus Network Journal, 2 I/2, 2019, pp. 227-252

Lobkowitz Juan Caramuel de (1678). Architectura civil recta y obliqua. En Vegeven: En la emprenta obispal por Camillo Corrado, | 678. <https://archive.org/details/architecturacivi00cara>

March Lionel, Steadman Philip (1974). The Geometry of Environment. Cambridge, Mass.:The MIT Press (First published London: RIBA Publications Limited, 1971)

Müller Emil (1913). Das Abbildungsprinzip. Jahresbericht der deutschen Mathematiker-Vereinigung 22/1913 Leipzig, pp 44-59. <https://www.deutsche-digitale-bibliothek.de/item/IDJMAWZO6S4ITCKBNVS62PIUPTE4ZKAD>.

Noebel Walter A. (ed.). (1982). Oswald Mathias Ungers. Die Thematisierung der Architektur. Neuauflage Zürich:Verlag Niggli.

Thompson D'Arcy Wentworth (2006). Über Wachstum und Form. Frankfurt a.M.: Eichborn. (Original: On Growth and Form. Cambridge: University Press, 1961).

\section{Author}

Cornelie Leopold,TU Kaiserslautern, Germany, cornelie.leopold@architektur.uni-kl.de

To cite this chapter. Cornelie Leopold (2020). Geometrische Transformationen als Entwurfsmethodik/Geometric transformations as design methodology. In Arena A., Arena M., Brandolino R. G., Colistra D., Ginex G., Mediati D., Nucifora S., Raffa P. (a cura di). Connettere. Un disegno per annodare e tessere. Atti del $42^{\circ}$ Convegno Internazionale dei Docenti delle Discipline della Rappresentazione/Connecting. Drawing for weaving relationships. Proceedings of the 42th International Conference of Representation Disciplines Teachers. Milano: FrancoAngeli, pp. I22I - I240. 